\title{
Upper tropospheric water vapour variability at high latitudes - Part 1: Influence of the annular modes
}

\author{
Christopher E. Sioris ${ }^{1}$, Jason Zou ${ }^{2}$, David A. Plummer ${ }^{3}$, Chris D. Boone ${ }^{4}$, C. Thomas McElroy ${ }^{1}$ Patrick E. Sheese $^{2}$, \\ Omid Moeini $^{1}$, and Peter F. Bernath ${ }^{4,5}$ \\ ${ }^{1}$ Department of Earth and Space Science and Engineering, York University, 4700 Keele St., Toronto, \\ ON, M3J 1P3, Canada \\ ${ }^{2}$ Department of Physics, University of Toronto, 60 St. George Street, Toronto, ON, M5S 1A7, Canada \\ ${ }^{3}$ Canadian Centre for Climate Modelling and Analysis, Environment Canada, Victoria, BC, Canada \\ ${ }^{4}$ Department of Chemistry, University of Waterloo, 200 University Ave. W, Waterloo, ON, N2L 3G1, Canada \\ ${ }^{5}$ Department of Chemistry \& Biochemistry, Old Dominion University, 4541 Hampton Blvd., Norfolk, \\ VA 23529, USA
}

Correspondence to: C. E. Sioris (csioris@sdcnlab.esse.yorku.ca)

Received: 3 July 2015 - Published in Atmos. Chem. Phys. Discuss.: 20 August 2015

Revised: 5 February 2016 - Accepted: 4 March 2016 - Published: 11 March 2016

\begin{abstract}
Seasonal and monthly zonal medians of water vapour in the upper troposphere and lower stratosphere (UTLS) are calculated for both Atmospheric Chemistry Experiment (ACE) instruments for the northern and southern high-latitude regions $\left(60-90^{\circ} \mathrm{N}\right.$ and $\left.60-90^{\circ} \mathrm{S}\right)$. Chosen for the purpose of observing high-latitude processes, the ACE orbit provides sampling of both regions in 8 of 12 months of the year, with coverage in all seasons. The ACE water vapour sensors, namely MAESTRO (Measurements of Aerosol Extinction in the Stratosphere and Troposphere Retrieved by Occultation) and the Fourier Transform Spectrometer (ACE-FTS) are currently the only satellite instruments that can probe from the lower stratosphere down to the midtroposphere to study the vertical profile of the response of UTLS water vapour to the annular modes.

The Arctic oscillation (AO), also known as the northern annular mode (NAM), explains $64 \%(r=-0.80)$ of the monthly variability in water vapour at northern high latitudes observed by ACE-MAESTRO between 5 and $7 \mathrm{~km}$ using only winter months (January to March, 2004-2013). Using a seasonal time step and all seasons, $45 \%$ of the variability is explained by the $\mathrm{AO}$ at $6.5 \pm 0.5 \mathrm{~km}$, similar to the $46 \%$ value obtained for southern high latitudes at $7.5 \pm 0.5 \mathrm{~km}$ explained by the Antarctic oscillation or southern annular mode (SAM). A large negative AO event in March 2013 produced the largest relative water vapour anomaly at $5.5 \mathrm{~km}(+70 \%)$
\end{abstract}

over the ACE record. A similarly large event in the 2010 boreal winter, which was the largest negative $\mathrm{AO}$ event in the record (1950-2015), led to $>50 \%$ increases in water vapour observed by MAESTRO and ACE-FTS at $7.5 \mathrm{~km}$.

\section{Introduction}

Water vapour is the most important greenhouse gas in the atmosphere (Lacis et al., 2010), playing an important role in climate change by magnifying changes in radiative forcing by longer-lived greenhouse gases through the water vapour feedback (Dessler and Sherwood, 2009). A variety of observations have shown that, at near-global scales, specific humidity in the troposphere has been increasing along with atmospheric temperatures in a manner consistent with that predicted by the Clausius-Clapeyron equation - approximately $7 \% \mathrm{~K}^{-1}$ (Hartmann et al., 2013). Long-term increases in water vapour are expected in the troposphere due to long-term increases in temperature and the resulting exponential increase in saturation vapour pressure (Soden and Held, 2006). In the stratospheric "overworld" (Dessler et al., 1995), long-term changes in water vapour may result from changes in the temperature of the tropical tropopause "coldpoint" that controls the dehydration of tropospheric air as it enters the stratosphere (Brewer, 1949) and from changes in 
its stratospheric source gas, namely methane (Oman et al., 2008). Water vapour in the extratropical lowermost stratosphere may be additionally influenced by changes in isentropic transport from the subtropics (Dessler et al., 2013). Additionally, absorption by atmospheric water vapour of radiation at terahertz and radio frequencies is a serious impediment for radio astronomy and for long-distance communications (Suen et al., 2014). The vertical distribution of water vapour is relevant for all of the effects mentioned.

In order to understand and attribute long-term changes, internal modes of variability, particularly those with longer periods, should be considered simultaneously. In the extratropics, the annular modes explain more of the month-tomonth and year-to-year variance of the atmospheric flow than any other climatic phenomenon (Thompson and Wallace, 2000; http://www.atmos.colostate.edu/ao/introduction.html). The northern and southern annular modes (NAM, SAM), also known as the Arctic oscillation (AO) and Antarctic oscillation (AAO), respectively, produce a strong zonal flow at mid-latitudes during their positive phase with an equatorward meridional flow near $60^{\circ}$ latitude, and weaker zonal flow during the negative phase accompanied by an increased tendency for poleward flow (Fig. 7 of Thompson and Wallace, 2000; Fig. 6 of Boer et al., 2001). Devasthale et al. (2012) used the Atmospheric Infrared Sounder (AIRS) on the Aqua satellite to study the longitudinal and vertical structure of water vapour in the $67-82^{\circ} \mathrm{N}$ band and interpreted the observed structure by separating the observations according to the phases of the Arctic oscillation. The impact of the Arctic and Antarctic oscillation on upper tropospheric water vapour (UTWV) has been studied by Boer et al. (2001) using a climate model with atmospheric and oceanic coupling and using the reanalysis data from the National Centers for Environmental Prediction.

The AO exhibits the largest variability during the cold season (Thompson and Wallace, 2000). Groves and Francis (2002) related TOVS (TIROS Operational Vertical Sounder) precipitable water vapour net fluxes across $70^{\circ} \mathrm{N}$ in winter to the phase of the AO. Li et al. (2014) showed that the longwave radiative forcing anomaly due to NAM-related variability of cold season water vapour for the 2006 to 2011 period at northern high latitudes is small $\left(\sim-0.2 \mathrm{~W} \mathrm{~m}^{-2}\right)$.

Here, the relationship between water vapour in the upper troposphere and lower stratosphere (UTLS) at northern and southern high latitudes (60-90 and $60-90^{\circ} \mathrm{N}$ ) and their respective annular modes is studied using observations from satellite-based limb profilers. A particular focus is the height dependence of the relationship: does it extend up to or above the tropopause?

\section{Method}

\subsection{Satellite observations}

SCISAT was launched in 2003, carrying a suite of solar occultation instruments to carry out the mission named the Atmospheric Chemistry Experiment (ACE) (Bernath et al., 2005). The ACE instruments measuring water vapour are Measurements of Aerosol Extinction in the Stratosphere and Troposphere Retrieved by Occultation (MAESTRO, McElroy et al., 2007) and the Fourier Transform Spectrometer (FTS, Bernath et al., 2005). The ACE data sets begin in February 2004. The measurements provide a unique combination of high vertical resolution and the ability to measure the water vapour profile from the mid-troposphere to the lower stratosphere, where the volume mixing ratio (VMR) is $<10 \mathrm{ppm}$ (parts per million), below the lower detection limit of the nadir-sounding AIRS (Gettelman et al., 2004). HIRS (High-Resolution Infrared Radiation Sounder) is the nadir sounder used in the last two Intergovernmental Panel on Climate Change (IPCC) assessments (e.g. Hartmann et al., 2013) for long-term trend studies of upper tropospheric humidity (Soden et al., 2005; Shi and Bates, 2011). However, the trend analysis of the HIRS data set is confined to the region $60^{\circ} \mathrm{N}$ to $60^{\circ} \mathrm{S}$ (Bates and Jackson, 2001). The Tropospheric Emission Spectrometer (TES) should also be mentioned, but in polar regions at pressures $<400 \mathrm{mb}$, the vertical resolution of TES is $11.6 \mathrm{~km}$ (Worden et al., 2004). IASI (Infrared Atmospheric Sounding Interferometer) water vapour retrievals have coarse vertical resolution in the polar upper troposphere, and the upper altitude limit of the retrieval only approaches the tropopause (Herbin et al., 2009; Wiegele et al., 2014). Other current limb sounders include the submillimetre radiometer on Odin which can only measure in the upper troposphere in the tropics (Rydberg et al., 2009) and the Microwave Limb Sounder on Aura which can only probe down to $316 \mathrm{mb}(\sim 8 \mathrm{~km})$ (Su et al., 2006). The fact that MAESTRO and ACE-FTS are on the same platform is extremely valuable for comparing the month-to-month variations of atmospheric constituents observed by both instruments.

The MAESTRO water vapour retrieval method follows the one used previously (Sioris et al., 2010). Data are available at https://databace.scisat.ca/level2/mae_water/ after user registration. Some of the main algorithm changes are described here. The maximum allowable optical depth in the water vapour fitting window $(926.0-969.7 \mathrm{~nm})$ is reduced from 7.63 to 6.7 . This reduces the number of noisy spectra but also possibly increases susceptibility to a dry bias at the lowest altitudes. Also, MODTRAN 5.2 (Berk, 2013, and references therein) is now used for forward modelling. The water vapour absorption line intensities are mostly from Brown et al. (2002) and have uncertainties of 2-5\%, an improvement relative to the previous version (Sioris et al., 2010), which used MODTRAN 4 (relying on the HITRAN 1996 spectro- 
scopic database). Water vapour profiles are retrieved from all available MAESTRO optical depth spectra (version 3.12, spanning 2004 to 2013) from the ongoing ACE mission. For version 3.12 optical depth spectra, the tangent height registration relies on matching simulated $\mathrm{O}_{2}$ slant columns obtained from air density profiles, based on temperature and pressure retrieved from ACE-FTS (Boone et al., 2013), with slant columns observed by MAESTRO using the $\mathrm{O}_{2} A$ band. MAESTRO water vapour mixing ratios that are more than twice as large as all other mixing ratios at any altitude in the same month were examined in detail and filtered if related to a measurement problem. Significant outliers are not numerous and no recursion is necessary. No other filtering is necessary. ACE-FTS gridded version 3.5 data are used in the study. The FTS retrieval is described by Boone et al. (2013). ACEFTS water vapour data with a retrieval uncertainty of $>100 \%$ are filtered as well as data points that are significantly negative (i.e. the magnitude of the mixing ratio is greater than the retrieval uncertainty). Polar Ozone and Aerosol Measurement III (POAM III) water vapour measurements are also used to compare the observed seasonal cycle. Only version 4 data (Lumpe et al., 2006) with a flag of 0 are used.

\subsection{Retrieval uncertainties and validation}

POAM III has been validated down to $8 \mathrm{~km}$ or $\sim 300 \mathrm{mb}$ (Nedoluha et al., 2002; Lumpe et al., 2006), and this is used as the POAM III lower altitude limit in this work. Previous comparisons between MAESTRO and ACE-FTS have been favourable (Sioris et al., 2010; Carleer et al., 2008). ACEFTS water vapour has been used in the validation of other instruments (e.g. Lambert et al., 2007) and in the Stratospheric Processes And their Role in Climate (SPARC) Data Initiative (Hegglin et al., 2013). Waymark et al. (2013) compared version 3 ACE-FTS water vapour data with the previous wellvalidated version 2.2 (e.g. Carleer et al., 2008) and found $2 \%$ differences over a large altitude range. Since the MAESTRO tangent height registration has improved substantially since the previous publication (Sioris et al., 2010), the current version of MAESTRO water vapour profiles has been validated in a global sense vs. ACE-FTS in the companion paper (Sioris et al., 2016).

Besides the validation results, it is also valuable to look at retrieval uncertainties to understand the expected data quality. Based on an analysis of 1 year of southern high-latitude data, the MAESTRO water vapour retrieval relative uncertainty is found to be best at the lowest retrieval altitude of $5 \mathrm{~km}$ and is typically $\sim 30 \%$ for a $0.4 \mathrm{~km}$ thick layer. The smallest retrieval relative uncertainty of $2 \%$ for ACE-FTS occurs typically at $8.5 \mathrm{~km}$ (considering 5.5 to $19.5 \mathrm{~km}$ ) and rapidly deteriorates below $7 \mathrm{~km}$ to $15 \%$ based on northern high-latitude data (2004-2013) on a $1 \mathrm{~km}$ altitude grid.

\subsection{Tropopause definitions}

For the Northern Hemisphere, the monthly tropopause height is defined as the height above $5 \mathrm{~km}$ that is the lower of the lowest local minimum or the lowest height at which the lapse rate is $<2 \mathrm{~K} \mathrm{~km}^{-1}$ in monthly median temperatures from the Global Environmental Multiscale (GEM) regional assimilation system (Laroche et al., 1999), sampled on the ACEFTS $1 \mathrm{~km}$ vertical grid. The lapse rate tropopause concept has been used previously for the extratropics (e.g. Randel et al., 2012). In the Southern Hemisphere, due to the winter lower stratosphere being colder than the tropopause region, the definition is the same, except that the lapse rate and lowest local minimum are determined using the monthly maximum temperature profile. Use of monthly median or mean profiles gives tropopauses that reflect the lower stratospheric temperature minimum, where ozone VMRs are also indicative of lower stratospheric air (i.e. $>150 \mathrm{ppm}$ ). The same problem is manifested when using a monthly average of tropopause heights determined from individual profiles. With the chosen definition, the climatological tropopause at southern high latitudes is at $10.5 \mathrm{~km}$ for the winter half of the year (May-October) and at $9.5 \mathrm{~km}$ in the summer half (November-April).

\subsection{Anomalies}

To arrive at water vapour anomalies, there are three steps: creation of the time series (e.g. monthly or seasonal), compilation of the climatology, and deseasonalization. Monthly time series are created at northern and southern high latitudes using occultation profiles in the $60-90^{\circ} \mathrm{N}$ and $60-90^{\circ} \mathrm{S}$ latitude bands, respectively. The sampling provided by the ACE orbit as a function of latitude and month is illustrated by Randel et al. (2012). The consequence of the non-uniform latitudinal sampling as a function of month for the purpose of this study is discussed in Sect. 2.5. This sampling pattern repeats annually. ACE instruments sample each high-latitude region in only 8 of 12 calendar months. November, January, MarchMay, and July-September represent spring, summer, autumn, and winter, respectively, when a seasonal timescale is used in the Southern Hemisphere. In the north, climatological values are obtained for all calendar months except April, June, August, and December. The seasonal anomalies use the following groupings at northern high latitudes: winter consists of January and February, spring includes March and May, summer is composed of July and September, and autumn is represented by October and November.

Vertically, the binning is done in $1.0 \mathrm{~km}$ intervals centered between 5.5 and $22.5 \mathrm{~km}$ (above $23 \mathrm{~km}$, the MAESTRO water vapour absorption signal tends to be below the lower detection limit). A month is included in the climatology and anomaly data set at any altitude where $\geq 20$ observations exist for that given month and altitude. A single MAESTRO profile can supply more than one observation per altitude bin 


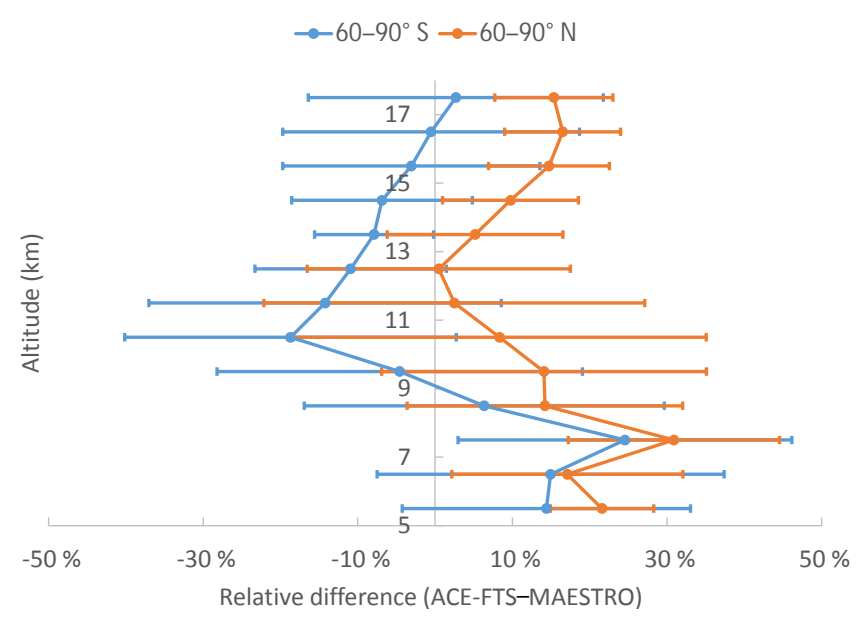

Figure 1. (Orange) Relative differences between ACE-FTS and MAESTRO climatological medians averaged over the 8 months of sampling the northern high-latitude region and their standard deviation; (blue) relative differences between ACE-FTS and MAESTRO climatological means averaged over the 8 months of sampling the southern high-latitude region and their standard deviation. The horizontal bars show the standard deviation of the differences between the two climatologies over the 8 available months. To account for vertical resolution differences, the MAESTRO climatology was vertically smoothed with a $3 \mathrm{~km}$ boxcar.

since the water vapour retrieval is done on the tangent height (TH) grid, which is as fine as $0.4 \mathrm{~km}$ at the lowest TH of $5 \mathrm{~km}$ and varies as the angle widens between line-of-sight and the orbital track. The same process is followed with ACE-FTS and POAM III data to generate monthly median and mean time series.

The monthly climatology, used to deseasonalize the time series, is generated by averaging the monthly medians and means over the available years. Figure 1 illustrates the relative difference between MAESTRO and ACE-FTS water vapour climatologies at both high-latitude bands. At southern high latitudes, monthly means are preferred for Fig. 1 and for the illustrated time series (Fig. 2) instead of medians which, for MAESTRO, have a dry bias in the widely dehydrated winter lower stratosphere. However, systematic and seasonally dependent biases cancel out given the sensor-specific deseasonalization as discussed at the end of this section, so only medians are used in the regression analyses (Sect. 2.5). An ACE-FTS high bias of $\sim 10 \%$ has been observed for the extratropical upper troposphere $\left(40-80^{\circ} \mathrm{N}\right.$ and $40-80^{\circ} \mathrm{S}$, near $300 \mathrm{hPa}$ ) (Hegglin et al., 2013). While inconclusive, a general wet bias between 5 and $8 \mathrm{~km}$ is also suggested by lidar comparisons in the extratropics (Carleer et al., 2008; Moss et al., 2013). Except below $8 \mathrm{~km}$ where a slight wet bias for ACE-FTS is likely, MAESTRO and ACE-FTS agree within $\pm 20 \%$ at all heights up to $17.5 \mathrm{~km}$ (in $1 \mathrm{~km}$ steps) in both hemispheres at high latitudes.
The monthly water vapour VMR time series are shown for the Southern and Northern Hemisphere in Figs. 2 and 3, respectively. At each height, the monthly climatology (e.g. Fig. 4) is subtracted from the time series (e.g. Fig. 2) to give the absolute deseasonalized anomaly. Dividing the monthly absolute anomaly by the monthly climatology gives the relative anomaly. Note that July and August 2011 were omitted from the MAESTRO southern high-latitude climatology at $6.5-9.5 \mathrm{~km}$ due to a $\sim 50 \%$ enhancement at these altitudes due to the Cordón Caulle volcanic eruption (Sioris et al., 2016). The same process is followed to generate anomalies of temperature, relative humidity $(\mathrm{RH})$, tropopause pressure, and tropopause height. The anomalies of relative humidity with respect to ice are based on pressure and temperature from the GEM assimilation system and an accurate saturation vapour pressure formulation (Murray, 1967). The latitude sampling anomaly is generated by calculating the monthly average of sampled latitudes for each high-latitude band and then the mission-averaged latitude in each highlatitude band is subtracted.

Note that, because conclusions below about the importance of the annular modes are reached based on water vapour anomalies and the fact the deseasonalization is sensor-specific (i.e. the time series observed by each instrument is deseasonalized using its own climatology), constant biases and seasonally dependent biases are actually inconsequential. Relevant biases are discussed in Sect. 2.5.

\subsection{Regression analysis}

We use a multiple linear regression analysis to determine the contribution of the appropriate annular mode to the variability in deseasonalized water vapour at high latitudes as a function of altitude. The set of available basis functions includes a linear trend, the monthly AAO (Mo, 2000) and AO (Larson et al., 2005) indices (http://www.cpc.noaa.gov/products/ precip/CWlink/), and the latitude sampling anomaly time series. This basis function is included to illustrate that sampling biases are minor even on a monthly timescale (using only the 8 months which sample each high-latitude region). Note that the AO index is calculated following the method of Thompson and Wallace (2000).

When determining the response of water vapour to the $\mathrm{AO}$, the AO index plus a constant are used, and the linear trend is included if it is significant at the 1 standard error $(\sigma)$ level. When examining trend uncertainty reduction (Sect. 4.2), the regression uses a linear trend, plus a constant; the annular mode index term is included for trend determination if it improves the trend uncertainty. Median water vapour anomalies are used in the analysis in both hemispheres since they respond with smaller uncertainty to the local annular mode than anomalies based on monthly means.

The types of biases that could affect the analysis of water vapour variability are due to

1. interannual variation in latitudinal sampling, and 


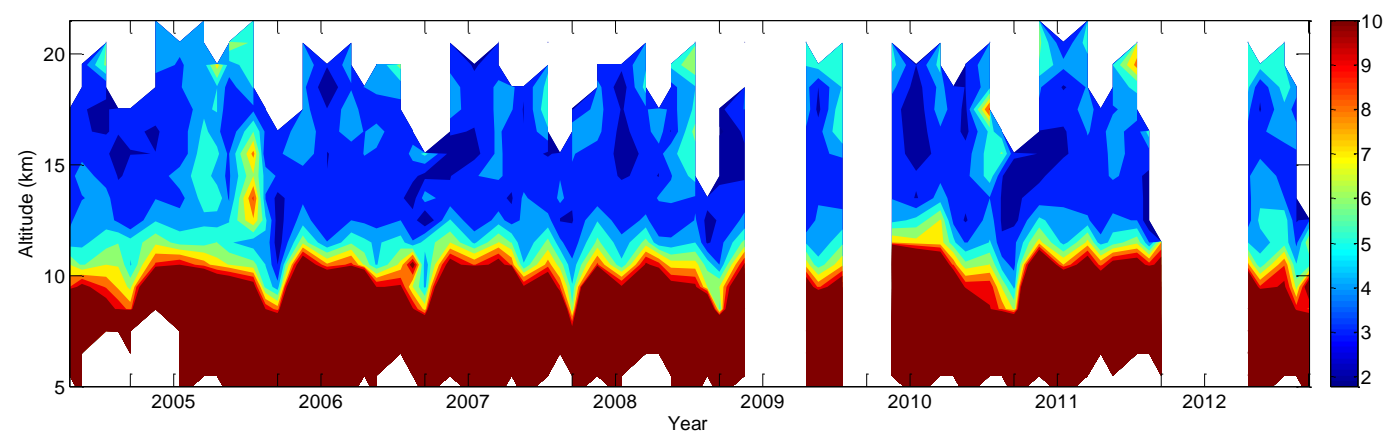

Figure 2. Time series of the MAESTRO monthly mean water vapour volume mixing ratio (VMR) vs. altitude (5.5-22.5 km) at southern high latitudes $\left(60-90^{\circ} \mathrm{S}\right)$ with a linear colour scale $(\mathrm{ppm})$, emphasizing the stratospheric variability. Unlabelled ticks along the bottom correspond to September. The time series is composed using the 8 months in which ACE samples the southern high latitudes (see Sect. 2.4).

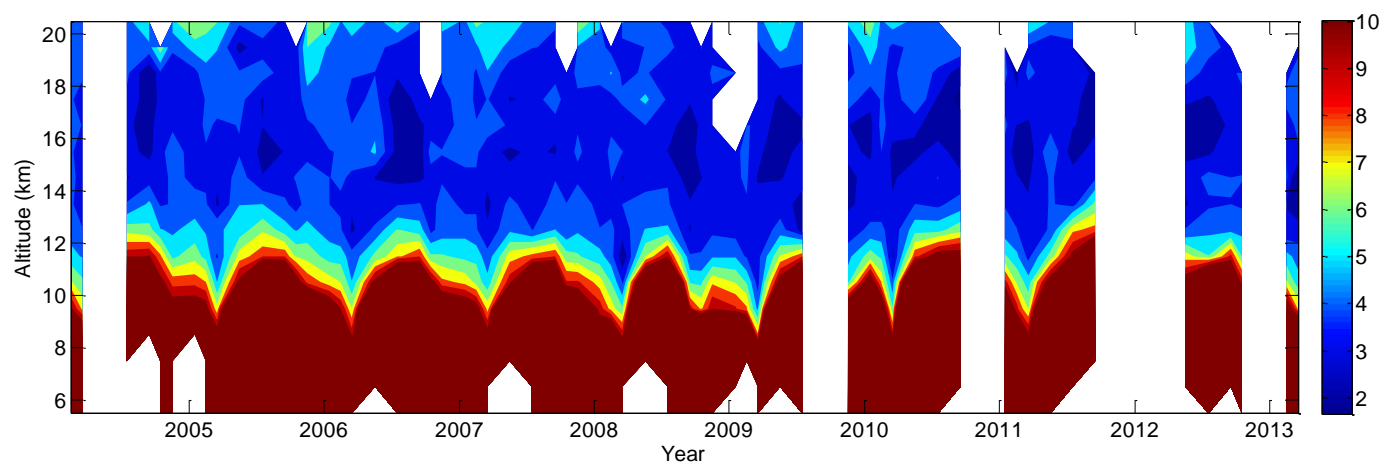

Figure 3. Time series of the MAESTRO monthly median water vapour volume mixing ratio (VMR) vs. altitude (km) at northern high latitudes $\left(60-90^{\circ} \mathrm{N}\right)$. The time series is composed using the 8 months in which ACE samples the northern high latitudes (see Sect. 2.4).

\section{2. interannual biases in retrieved water vapour profiles.}

Regarding the non-uniform sampling of latitudes by the ACE orbit mentioned in Sect. 2.4, the correlation between monthly time series of average sampled latitude in the northern highlatitude region and the Arctic oscillation index is 0.19 , and similarly the correlation between the monthly time series of average sampled latitude in the southern high-latitude region and the Antarctic oscillation index is 0.12 . Given these very low correlations, ACE's latitudinal sampling should have a negligible impact on any conclusion about the response of the observed water vapour anomaly to the annular modes, although this is tested below using the latitude sampling anomaly as a basis function. Toohey et al. (2013) estimated monthly mean sampling biases in the UTLS to be $\leq 10 \%$ for the category of instruments that includes ACE-FTS (and MAESTRO). The interannual biases are also $<10 \%$ given that Sect. 3.2 below shows that approximately half of the southern high-latitude water vapour seasonal anomaly (typically $\pm 10 \%$ in amplitude) can be explained by interannual variability in the Antarctic oscillation (i.e. real dynamical variability, not artificial instrument-related variability). Also, there are no known issues with either MAESTRO or ACE-FTS specific to a certain year. Furthermore, the self-calibrating nature of solar occultation, combined with the wavelength stability of spectrometers (relative to filter photometers) minimize interannual bias for MAESTRO and ACE-FTS. For example, any variation in the optical (or quantum) efficiency of the instrument does not need to be calibrated as it does with an instrument measuring nadir radiance.

\section{Results}

The MAESTRO water vapour record (Fig. 2) at southern high latitudes is similar to the records of contemporary limb sounders as shown in Fig. 13 of Hegglin et al. (2013).

\subsection{Seasonal cycle}

The dehydration in September that extends downward into the upper troposphere at southern high latitudes (Fig. 4) is clearly observed by MAESTRO annually (Fig. 2).

The variability in the UTWV at southern high latitudes on a monthly timescale is dominated by the seasonal cycle. The observed seasonal variation is a factor of $\sim 5$ at $8.5 \mathrm{~km}$ (Fig. 5). The seasonal cycle in water vapour is con- 


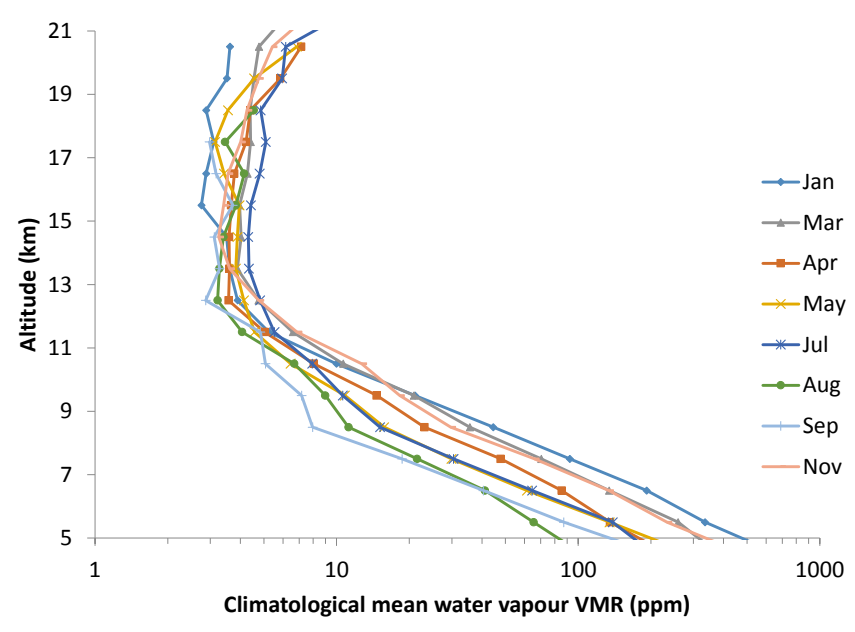

Figure 4. MAESTRO mean climatology (2004-2012) of the vertical distribution of the water vapour volume mixing ratio in the Antarctic $\left(60-90^{\circ} \mathrm{S}\right)$ UTLS for months with sufficient sampling of the region. A logarithmic scale is used for the $x$ axis.

sistent with the ratio of the maximum to minimum saturation vapour mixing ratio at $8.5 \mathrm{~km}$ of $4.6( \pm 1$ standard deviation: 3.9-5.3), obtained for a typical year, namely 2010, using analysis temperatures and pressures from the GEM assimilation system, sampled at ACE measurement locations for January and August, the months corresponding to the maximum and minimum water vapour in ACE-FTS and POAM III data at $8.5 \mathrm{~km}$, respectively. The approximate equality between the seasonal cycle amplitudes of observed and saturation VMR in the troposphere implies a much weaker seasonal cycle in RH. The strong seasonal cycle in UTWV is in stark contrast to weak $(30 \%)$ seasonal variations in lower stratospheric $(13.5 \mathrm{~km})$ monthly means, according to MAESTRO observations. The large seasonal cycle amplitude in saturation vapour mixing ratio in the lower stratosphere is largely due to the extremely cold temperatures in September.

The stronger seasonal cycle at northern high latitudes (e.g. at $5.5 \mathrm{~km}$, Fig. 6) is partly due to the non-uniform latitudinal sampling differences in the months of maximum and minimum water vapour VMR, particularly in the Southern Hemisphere. The Northern Hemisphere seasonal cycle amplitude vertical profile (Fig. 6) is thus a truer reflection of the amplitude of the seasonal cycle at high latitudes. Figures 5 and 6 illustrate that the seasonal cycle amplitude of observed water vapour VMR in the lower stratosphere departs from the seasonal cycle amplitude of the saturation vapour VMR due to the isolation of this overlying atmospheric region from large sources of water vapour. According to GEM temperature analyses, the amplitude of the seasonal cycle in temperature is $18 \mathrm{~K}$ with a sharp peak in mid-summer (e.g. July), and is generally sufficient to explain the seasonal variation of water vapour VMR and its vertical dependence in the upper troposphere (Fig. 6).

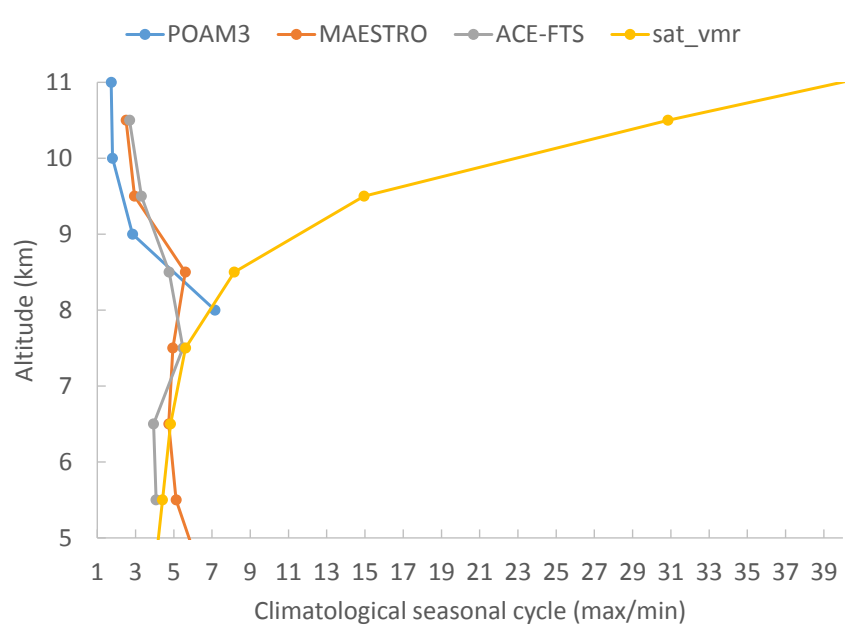

Figure 5. Vertical profile of the seasonal cycle amplitude of Antarctic water vapour observed by three instruments. The amplitude is calculated by taking the ratio of climatological monthly means at maximum (January or December) and minimum (August or September). Note that POAM III has a different orbit that tends to sample consistently at higher latitudes (Nedoluha et al., 2002) and thus tends to have stronger seasonality at $8 \mathrm{~km}$ (driven by the larger temperature range). The saturation vapour pressure climatology is obtained using GEM analysis temperatures sampled at ACE measurement locations.

In spite of the large tropospheric seasonality at high latitudes, it is possible to deseasonalize the water vapour records from the ACE instruments and investigate the remaining sources of temporal variability, as shown next.

\subsection{Antarctic oscillation}

At $8.5 \mathrm{~km}$, where the largest anti-correlations exist between MAESTRO water vapour at $8.5 \mathrm{~km}$ and the AAO index, it is observed that the relative standard error on the AAO fitting coefficient is reduced when the regression is performed using a seasonal timescale rather than a monthly timescale. Thus, in Fig. 7, the MAESTRO and ACE-FTS seasonal median relative anomalies for $8.5 \pm 0.5$ and $7.5 \pm 0.5 \mathrm{~km}$, respectively, are presented. The use of medians is preferable for detecting the annular mode response in the troposphere in both hemispheres since this measure of central tendency is less susceptible to remaining outliers in the individual retrieved profiles and because smaller standard errors for the AAO fitting coefficient are obtained. The large positive anomaly in 2011 is due to the most explosive eruption of a volcano in the last 24 years, namely Cordón Caulle, and will be discussed in the companion paper (Sioris et al., 2016).

At $8.5 \mathrm{~km}$, where the response of water vapour to AAO has the smallest relative uncertainty for both ACE-FTS and MAESTRO, the response ranges between +23 and $-18 \%$ for individual seasons and the standard deviation of the AAO response time series is $10 \%$ (2004-2012). The anomalies in 


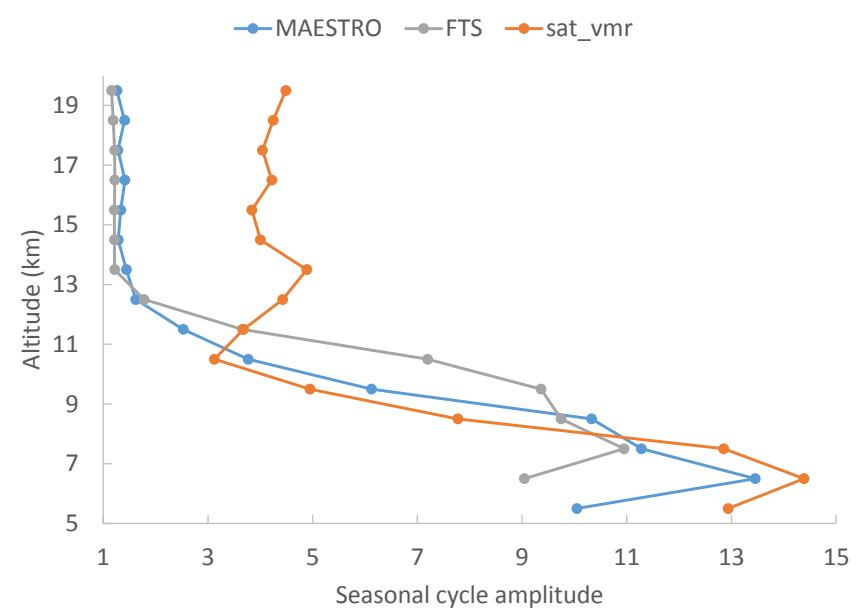

Figure 6. Analogous to Fig. 5 but for northern high latitudes. Profiles are presented at their respective native vertical resolutions.

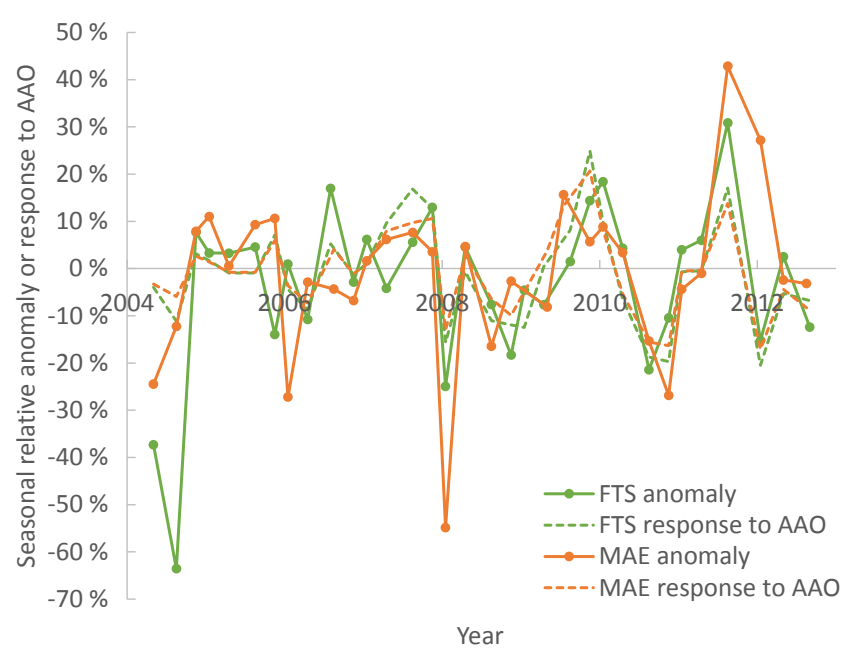

Figure 7. Seasonal median water vapour anomaly time series from MAESTRO $(8.5 \mathrm{~km})$ and ACE-FTS $(7.5 \mathrm{~km})$ in the Antarctic troposphere and the response of each to AAO determined by linear regression. Seasons with missing data are removed to avoid discontinuities. The markers on the response curves indicate the sampled seasons.

the upper troposphere are highly correlated with each other (e.g. $R=0.79$ for MAESTRO absolute anomalies at $8.5 \mathrm{vs}$. $9.5 \mathrm{~km}$ on a monthly timescale). In the stratosphere (altitude $\geq 10 \mathrm{~km}$ ), the response of MAESTRO water vapour to AAO is weak (not significant). Figure 8 illustrates the vertical profile of the AAO response. There is a strong vertical correlation between the water vapour responses to the AAO observed by the two instruments and the responses are statistically significant (up to the $4 \sigma$ level for ACE-FTS at $7.5 \mathrm{~km}$ ) in the $5.5-8.5 \mathrm{~km}$ for both instruments, indicating that the AAO affects water vapour throughout the upper troposphere at southern high latitudes. The MAESTRO and

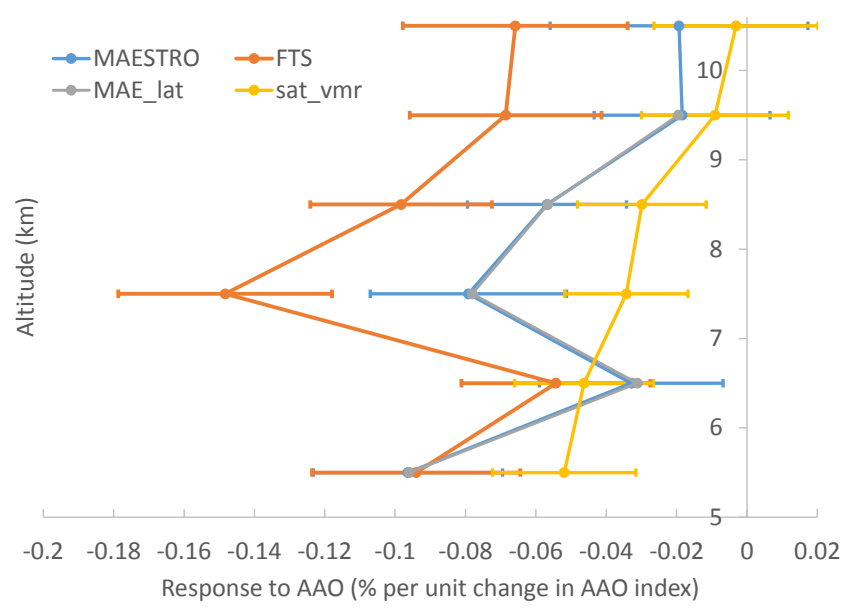

Figure 8. Vertical profile of response to AAO, using southern highlatitude water vapour relative anomalies based on monthly medians (2004-2012). Horizontal bars are $\pm 1 \sigma$, obtained by linear regression (including a trend term and/or a Cordón Caulle proxy term, depending on whether each is significant at the $1 \sigma$ level). The MAE_lat profile shows the MAESTRO water vapour response to AAO upon including a basis function to account for the nonuniform latitudinal sampling. The sat_vmr profile is obtained from a simple linear regression of saturation vapour VMR relative anomalies onto AAO.

ACE-FTS AAO fitting coefficients are not different from 0 at the $1 \sigma$ level at 10.5 and $11.5 \mathrm{~km}$, respectively. Slight differences between the ACE instruments may relate to differences in their respective fields of view (FOVs). MAESTRO's FOV is $1 \mathrm{~km}$ in the vertical direction, whereas ACE-FTS, because of its $3.7 \mathrm{~km}$ circular FOV at a tangent point $10 \mathrm{~km}$ above the ground, will see some contribution from the troposphere even when the FOV is centered $1.5 \mathrm{~km}$ above the tropopause. Given that the ACE-FTS FOV is circular, the full-width at half-maximum of the FOV is $3.2 \mathrm{~km}$. Due to vertical oversampling of the FOV, the vertical resolution of the water vapour products from each ACE instrument is finer than the height of the FOV (see also Sioris et al., 2010). Nevertheless, differences in vertical resolution between the ACE instruments will lead to a slight difference in terms of the peak altitude of the anti-correlation between the water vapour anomaly and AAO. The impact of non-uniform latitudinal sampling is deferred to Sect. 3.3. The response profile of saturation volume mixing ratio to the $\mathrm{AAO}$ is also shown and is discussed in Sect. 4.3.

\subsection{Arctic oscillation}

Figure 9 shows the altitude dependence of observed water vapour response to the Arctic oscillation using all 8 months that sample the northern high-latitude region. There is a coherent and statistically significant response (up to the $4 \sigma$ level for MAESTRO) to the AO observed by both instruments, with a general decrease through the upper troposphere 


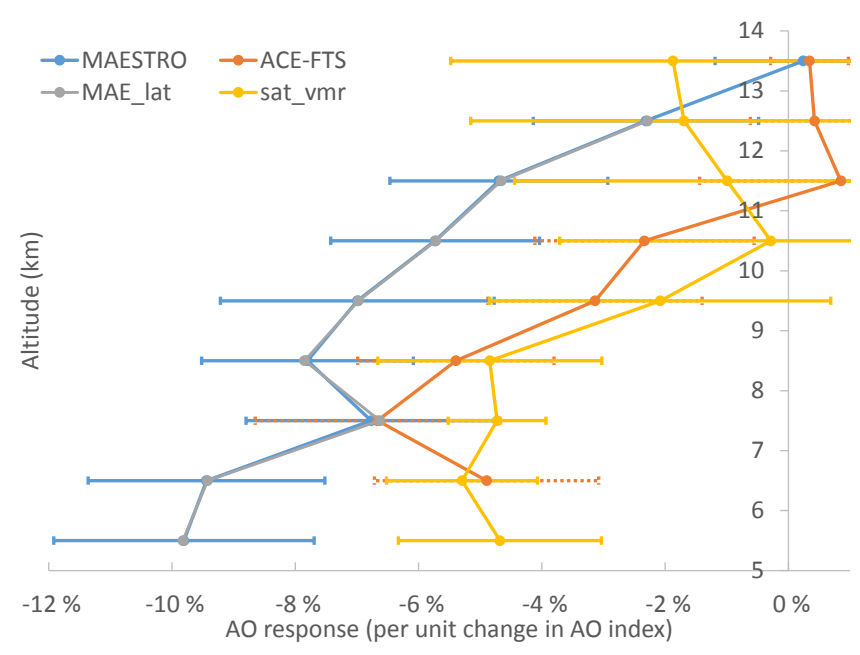

Figure 9. Analogous to Fig. 8, but for northern high-latitude water vapour in response to the Arctic oscillation. Error bars display \pm 1 standard error of the fitting coefficient for the AO index obtained by linear regression. At $5.5 \mathrm{~km}$, the response of ACE-FTS is not shown since it has a standard error of $>100 \%$ and the sample size decreases significantly.

and a vanishing response in the vicinity of the tropopause. Above $12 \mathrm{~km}$, the response to the $\mathrm{AO}$ is insignificant at the $1 \sigma$ level. The magnitude of the response to the $\mathrm{AO}$ is also similar to the magnitude of the response of UTWV at southern high latitudes to the Antarctic oscillation.

The spatiotemporal sampling of ACE (Bernath et al., 2005 ) is quite non-uniform on monthly timescales, whereas on seasonal timescales the spatial coverage of the entire highlatitude region becomes more complete. When the latitudinal sampling anomaly is used as a basis function in fitting monthly water vapour anomaly time series, it is generally not a significant term in either hemisphere. Fig. 9 shows that the inclusion of this term does not change the response to the $\mathrm{AO}$, reinforcing the same finding for the response to the AAO (Fig. 8). Clearly, water vapour at high latitudes responds with high fidelity to the local annular mode.

Using the MAESTRO water vapour anomalies, a seasonal time step, and all seasons, $45 \%$ of the variability is explained at $6.5 \pm 0.5 \mathrm{~km}$, similar to the fraction obtained for southern high latitudes.

The most active season for the AO is from January to March based on monthly standard deviations of the AO index in the period from 1950 to 2015. This 3-month period was used by Thompson and Wallace (2000). Figure 10 shows a water vapour anomaly time series for an altitude of $6.5 \mathrm{~km}$, composed only of January, February, and March (2004-2013). The wintertime anti-correlation between the ACE-FTS water vapour anomaly and the AO index peaks at $6.5 \mathrm{~km}$ with $R=-0.57$. MAESTRO shows a much stronger anti-correlation of $R=-0.80$ at 6.5 and $5.5 \mathrm{~km}$. A large negative AO event in March 2013 produced the largest rel-

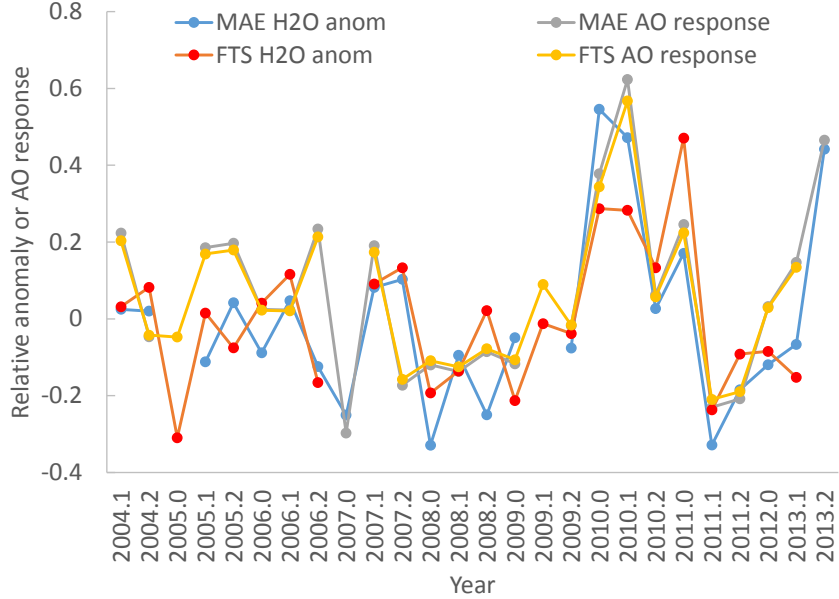

Figure 10. Time series of water vapour relative anomalies observed by ACE-MAESTRO ("MAE") and ACE-FTS at $6.5 \pm 0.5 \mathrm{~km}$ in winter months (January-March). Slight differences in sampling exist between the two instruments due to the requirement for $>20 \mathrm{ob}-$ servations per month per altitude bin.

ative water vapour anomaly at $5.5 \mathrm{~km}(+70 \%)$ over the MAESTRO record. March 2013 was not available below $8 \mathrm{~km}$ for ACE-FTS, but at 8.5 and $9.5 \mathrm{~km}$, ACE-FTS and MAESTRO both show the largest positive anomalies for any March in either northern high-latitude data record $(+32$ and $+35 \%$ at $8.5 \mathrm{~km}$ and +16 and $+27 \%$ at $9.5 \mathrm{~km}$ for MAESTRO and ACE-FTS, respectively) and a vanishing enhancement at $10.5 \mathrm{~km}$ (above the monthly mean tropopause). A similarly large event in winter 2010, which was the largest negative AO event in the record (1950-2015), led to $>50$ and $30 \%$ increases in northern high-latitude water vapour observed at $7.5 \mathrm{~km}$ in January and February 2010, respectively, with agreement between MAESTRO and ACEFTS. January 2010 has the largest anomaly at $7.5 \mathrm{~km}$ in any month (considering all seasons) of the northern highlatitude data records of MAESTRO and ACE-FTS. Steinbrecht et al. (2011) used a multiple linear regression analysis to demonstrate a significant increase in total column ozone (+8 Dobson units) in the winter of 2010 that was attributed to the same historically strong negative phase of the Arctic oscillation.

\section{Discussion and conclusions}

Polar regions have a strong seasonal cycle in UTWV, which is consistent with the seasonality of the local temperature. The importance of the seasonal cycle in local temperature for UTWV seasonality at high latitudes has been stated previously (Chen et al., 1999). On the basis of general circulation model simulations, Del Genio et al. (1994) demonstrated that small-scale moist convection and the mean meridional circu- 
lation have a minor role in the seasonal cycle of polar UTWV, and that the primary mechanism is eddy moisture fluxes.

In the Arctic upper troposphere, condensation and precipitation play a minor role in governing the water vapour abundance on monthly timescales. Near the Arctic tropopause (250-350 mb), cloud fractions are <35\% (Treffeisen et al., 2007) and MAESTRO monthly median relative humidity at $9.5 \mathrm{~km}$ is $<40 \%$ in all 63 months in which this instrument has observed the northern high-latitude region. However, dynamical variability via the annular modes has been shown here to strongly affect UTWV at high latitudes. Apart from the seasonal cycle, the Antarctic oscillation is a dominant mode of variability in upper tropospheric $(\sim 8 \mathrm{~km})$ water vapour at southern high latitudes on a seasonal timescale, and the Arctic oscillation explains most of the variability in wintertime UTWV at northern high latitudes.

\subsection{Radiative impact}

As stated in Sect. 1, the AO is most active in the winter, when the surface is coldest. Therefore less infrared (IR) radiation is emitted and trapped by AO-related increases in atmospheric water vapour. Over Antarctica, the AAO instead shows strength in late spring (Thompson and Wallace, 2000) at a time when there is increased IR radiation emitted by the surface, possibly making AAO-related water vapour changes more likely to lead to increases in temperature at the surface and to reduce outgoing longwave flux at the top of the atmosphere (TOA). The impact of AAO-induced variability of upper tropospheric water vapour on surface climate and outgoing longwave flux at the top of the atmosphere is assessed for November 2009 and November 2010, 2 months when the AAO was of opposite phase (see Appendix A for details of the method). The cooling rate differences at the surface between these negative and positive phases of the AAO are trivial $(<0.07 \mathrm{~K})$ in late spring (November). The outgoing longwave flux is reduced by $0.7 \mathrm{~W} \mathrm{~m}^{-2}$ in November 2009 relative to November 2010 due solely to AAO-related upper tropospheric changes in water vapour. Scaling this change to the typical AAO fluctuation in all seasons (1979-2014), variations of $0.2 \mathrm{~W} \mathrm{~m}^{-2}$ are estimated in the outgoing longwave flux at the TOA, which are equal to the magnitude $\mathrm{Li}$ et al. (2014) found for the AO-related IR flux changes at TOA due to water vapour for the Arctic cold season. Note that $\mathrm{Li}$ et al. (2014) found the AO-related water vapour changes to be much smaller than AO-related cloud changes.

\subsection{Impact of fitting annular mode indices on decadal trends}

In the most recent IPCC report, Hartmann et al. (2013) review the literature on trends in UTWV observed from satellite instruments. Only one such publication is cited, namely Shi and Bates (2011). This work uses HIRS data between $85^{\circ} \mathrm{N}$ and $85^{\circ} \mathrm{S}$, but only trends at low latitudes $\left(30^{\circ} \mathrm{N}-\right.$ $30^{\circ} \mathrm{S}$ ) are discussed. While long-term trends in polar UTWV require continued measurements and investigation, including the $\mathrm{AO}$ index in the trend analysis improves trend uncertainties below $12 \mathrm{~km}$ over the MAESTRO record (e.g. by $16 \%$ at $6.5 \mathrm{~km})$ and reduces a statistically insignificant $(1 \sigma)$ but consistent positive bias in the decadal trend (2004-2013) that is found when the $\mathrm{AO}$ is excluded from the regression model. This bias stems from the two large negative events in the winters of 2010 and 2013, which lie near the end of the data record. The trend uncertainty reduction is $22 \%$ upon inclusion of the Antarctic Oscillation Index in regression modelling of the linear trend in water vapour at $8.5 \mathrm{~km}$ at southern high latitudes, again with no significant impact on the linear trend itself.

\subsection{Proposed mechanisms}

The amplitude of the response by water vapour to annular mode oscillations does not change significantly $(1 \sigma)$ whether UTWV is binned vs. altitude or geopotential altitude in either hemisphere at high latitudes, indicating the insensitivity to the choice of vertical coordinate. This is important to note, as the correlation of other atmospheric variables with the annular modes is explored in this section.

There is some observational evidence for two mechanisms that could explain how UTWV at high latitudes responds to the annular modes. The first is through annular-mode-related air temperature fluctuations (Thompson and Wallace, 2000), which impact UTWV by changing the saturation vapour mixing ratio. For changes in the saturation vapour mixing ratio to have an impact, there needs to be an available supply of upper tropospheric water vapour.

The second mechanism is through changes to the mean meridional flux itself (e.g. Boer et al., 2001; Devasthale et al., 2012; Thompson and Wallace, 2000), given the latitudinal gradient in water vapour between high and mid latitudes at all upper tropospheric heights. Boer et al. (2001) have already demonstrated the response of mean meridional flux of UTWV to the annular modes using climate model simulations. However, poleward isentropic transport may involve ascent, which may lead to condensation when RH reaches $100 \%$. If sufficient water vapour condenses, precipitation may occur, which would lower the local VMR of water vapour. But evaporation and condensation play a minor role in the polar tropospheric water budget (Boer et al., 2001 ), with water vapour representing $99 \%$ of the total water content (Jakobson and Vihma, 2010, and references therein). There are many additional, related arguments in favour of the Eulerian mean meridional circulation as a plausible mechanism to account for the response of high-latitude UTWV to the annular modes. Firstly, the high-latitude upper troposphere has low RH $(<50 \%)$, with the exception of autumn (e.g. March-April in the Southern Hemisphere). Secondly, in this autumnal period of higher RH (e.g. $60 \%$ below $8 \mathrm{~km}$ ), the annular mode activity is low for either hemi- 
sphere and, conversely, the active period for either annular mode falls in a season of low RH. Thirdly, the vertical component of the meridional circulation tends to shift downward during the negative phase of the local annular mode in either hemisphere (Fig. 7 of Thompson and Wallace, 2000), thereby reducing the likelihood of condensation. Fourth, ice crystals formed during poleward ascending motion will tend to return to the vapour phase before precipitating, given the dry, surrounding air (e.g. Prospero et al., 1983). Finally, precipitation may evaporate before descending into the lower troposphere given the vertical gradient in ambient temperature. These five additional arguments suggest that the meridional flux mechanism could be effective in transporting water vapour to the high-latitude upper troposphere on a monthly timescale during the negative phase of the annular mode. Boer et al. (2001) showed that there is an increased poleward upper tropospheric moisture flux via the meridional mean circulation at high latitudes during the negative phase of the annular mode in either hemisphere. According to the analysis of Boer et al. (2001), the mean meridional flow mechanism appears to be of greater relative importance in the high-latitude upper troposphere in the Southern Hemisphere. The effectiveness of the mean meridional flux mechanism in increasing UTWV VMR during negative AAO periods is amplified by the large latitudinal gradients in UTWV between southern mid and high latitudes. Note that these two mechanisms are not correlated spatially with each other to a high degree. This has been verified using the latitude and altitude dependence of their responses to the annular modes (Thompson and Wallace, 2000). The two mechanisms are complementary in that they both increase UTWV at high latitudes during the negative phase of the local annular mode.

There are other mechanisms that are considered, such as tropopause variations (discussed below) and meridional eddy moisture fluxes (Boer et al., 2001). As mentioned above, eddies are primarily responsible for the seasonal cycle of UTWV (Del Genio et al., 1994). However, Boer et al. (2001) clearly show for both hemispheres that annular-mode-related moisture fluxes via eddies are small (relative to the mean meridional flux) and of the wrong sign to explain the poleward transport of moisture in the high-latitude upper troposphere. However, only the meridional eddy flux term was considered, whereas Del Genio et al. (1994) point out that large-scale eddies transport moisture upward as well as poleward.

We see no evidence in either high-latitude region of a fourth mechanism whereby the UTWV anomalies are simply explained by annular-mode-driven tropopause variations: the correlation between tropopause height or tropopause pressure anomalies and the relevant annular mode is not significant in either high-latitude region $(-0.1<R<0.1)$. This is not surprising given that the magnitude of responses of water vapour and saturation vapour VMR to the annular modes diminish with increasing height toward the tropopause (Figs. 8-9). According to several studies (e.g. Cai and Ren,
2007; Ambaum and Hoskins, 2002; Highwood et al., 2000), the high-latitude tropopause tends to rise during the positive phase of the AO. Therefore, the response of the tropopause to the AO is of the wrong sign to explain increases in UTWV during the negative phase of the AO.

We proceed in this discussion considering only the first two mechanisms since they are supported by previous studies. The response profile of saturation vapour VMR relative anomalies (from analyses of the GEM assimilation system) to the AAO (Fig. 8) is studied in order to isolate and gain insight into the contribution of the first proposed mechanism.

Below $9 \mathrm{~km}$, the response of saturation vapour VMR tends to be weaker than the response by deseasonalized water vapour observed by the ACE instruments, implying that the temperature mechanism cannot fully explain the strong observed response of water vapour to the AAO at southern high latitudes (Fig. 8). Near the tropopause $(9.5-10.5 \mathrm{~km})$, the response of saturation vapour VMR to the AAO becomes effectively zero (within $1 \sigma$ ), but the response of observed water vapour to the AAO also decreases considerably relative to lower altitudes. The response of water vapour to the AAO differs significantly between MAESTRO and ACEFTS, except at 5.5 and $6.5 \mathrm{~km}$, making it generally difficult to unequivocally determine the contribution of the first proposed mechanism. Nevertheless, there is an obvious need for a mechanism in addition to the temperature-related one to explain the observed response of water vapour in the southern high-latitude upper troposphere. This is consistent with the correlation between the annular mode and mean meridional moisture flux, particularly in the Southern Hemisphere (Boer et al., 2001).

At northern high latitudes (Fig. 9), saturation vapour VMR responds to the $\mathrm{AO}$ in a similar fashion to its response to the $\mathrm{AAO}$ at southern high latitudes. The response of saturation vapour VMR to the $\mathrm{AO}$ at northern high latitudes tends to be smaller in magnitude than the response by water vapour inferred from ACE observations, but the difference is not statistically significant at all altitudes compared to the ACE-FTS water vapour response. The water vapour anomalies from the two ACE instruments show a decreasing response to the AO with increasing altitude at northern high latitudes, but generally differ in the magnitude of the response, as is the case as well at southern high latitudes. Thus, no general conclusion can be unequivocally drawn about the sufficiency of the first proposed mechanism in the northern high-latitude upper troposphere.

The relative contributions by the different mechanisms involved in the response of water vapour to the annular modes remain uncertain partly due to significant intersensor differences (Figs. 8-9). Longer data sets and further analysis would be helpful to understand the contribution by the proposed mechanisms. 


\section{Appendix A: Cooling rate differences}

Cooling rate vertical profiles are calculated using MODTRAN5.2 (e.g. Bernstein et al., 1996) assuming an Antarctic surface altitude of $2.5 \mathrm{~km}$, a subarctic summer temperature profile, free tropospheric aerosol extinction (visibility of $50 \mathrm{~km}$ ), and two water vapour cases

1. using MAESTRO climatological median water vapour between 6.5 and $9.5 \mathrm{~km}$ increased by the vertically resolved water vapour response to AAO determined by multiple linear regression (with AAO and constant as the only predictors) for November 2009, when the AAO was in its negative phase (index of -1.92); and

2. same as (1), except for November 2010, when the AAO index was +1.52 (positive phase). 
Acknowledgements. The availability of the NOAA annular mode indices is appreciated. The ACE mission is supported primarily by the Canadian Space Agency. POAM III data were obtained from the NASA Langley Research Center Atmospheric Science Data Center. C. E. Sioris is grateful to Frédéric Laliberté (Environment Canada) for a helpful discussion on separating the contributions by the two mechanisms proposed in Sect. 4.3. The three referees and the editor are thanked for greatly improving the article.

Edited by: T. von Clarmann

\section{References}

Ambaum, M. H. P. and Hoskins, B. J.: The NAO tropospherestratosphere connection, J. Climate, 10, 1969-1978, 2002.

Bates, J. J. and Jackson, D. L.: Trends in upper-tropospheric humidity, Geophys. Res. Lett., 28, 1695-1698, 2001.

Berk, A.: Voigt equivalent widths and spectral-bin single-line transmittances: Exact expansions and the MODTRAN ${ }^{\circledR} 5$ implementation, J. Quant. Spectrosc. Ra., 118, 102-120, 2013.

Bernath, P. F., McElroy, C. T., Abrams, M. C., Boone, C. D., Butler, M., Camy-Peyret, C., Carleer, M., Clerbaux, C., Coheur, P.-F., Colin, R., DeCola, P., DeMazière, M., Drummond, J. R., Dufour, D., Evans, W. F. J., Fast, H., Fussen, D., Gilbert, K., Jennings, D. E., Llewellyn, E. J., Lowe, R. P., Mahieu, E., McConnell, J. C., McHugh, M., McLeod, S. D., Michaud, R., Midwinter, C., Nassar, R., Nichitiu, F., Nowlan, C., Rinsland, C. P., Rochon, Y. J., Rowlands, N., Semeniuk, K., Simon, P., Skelton, R., Sloan, J. J., Soucy, M.-A., Strong, K., Tremblay, P., Turnbull, D., Walker, K. A., Walkty, I., Wardle, D. A., Wehrle, V., Zander, R., and Zou, J.: Atmospheric Chemistry Experiment (ACE): mission overview, Geophys. Res. Lett., 32, L15S01, doi:10.1029/2005GL022386, 2005.

Bernstein, L. S., Berk, A., Acharya, P. K., Robertson, D. C., Anderson, G. P., Chetwynd, J. H., and Kimball, L. M.: Very narrow band model calculations of atmospheric fluxes and cooling rates, J. Atmos. Sci., 53, 2887-2904, 1996.

Boer, G. J., Fourest, S., and Yu, B.: The signature of the annular modes in the moisture budget, J. Climate, 14, 3655-3665, 2001.

Boone, C. D., Walker, K. A., and Bernath, P. F.: Version 3 retrievals for the Atmospheric Chemistry Experiment Fourier Transform Spectrometer (ACE-FTS), in: The Atmospheric Chemistry Experiment ACE at 10: A Solar Occultation Anthology, edited by: Bernath, P. F., A. Deepak Publishing, Hampton, Virginia, 103127, 2013.

Brewer, A. W.: Evidence for a world circulation provided by the measurements of helium and water vapour distribution in the stratosphere, Q. J. Roy. Meteor. Soc., 75, 351-363, 1949.

Brown, L. R., Toth, R. A., and Dulick, M.: Empirical line parameters of $\mathrm{H}_{2}^{16} \mathrm{O}$ near $0.94 \mu \mathrm{m}$ : Positions, intensities and airbroadening coefficients, J. Mol. Spectrosc., 212, 57-82, 2002.

Cai, M. and Ren, R.-C.: Meridional and downward propagation of atmospheric circulation anomalies. Part I: Northern hemisphere cold season variability, J. Atmos. Sci., 64, 1880-1901, 2007.

Carleer, M. R., Boone, C. D., Walker, K. A., Bernath, P. F., Strong, K., Sica, R. J., Randall, C. E., Vömel, H., Kar, J., Höpfner, M., Milz, M., von Clarmann, T., Kivi, R., Valverde-Canossa, J., Sioris, C. E., Izawa, M. R. M., Dupuy, E., McElroy, C. T.,
Drummond, J. R., Nowlan, C. R., Zou, J., Nichitiu, F., Lossow, S., Urban, J., Murtagh, D., and Dufour, D. G.: Validation of water vapour profiles from the Atmospheric Chemistry Experiment (ACE), Atmos. Chem. Phys. Discuss., 8, 4499-4559, doi:10.5194/acpd-8-4499-2008, 2008.

Chen, M., Rood, R. R., and Read, W. G.: Seasonal variations of upper tropospheric water vapor and high clouds observed from satellites, J. Geophys. Res., 104, 6193-6197, 1999.

Del Genio, A. D., Kovari Jr., W., and Yao, M.-S.: Climatic implications of the seasonal variation of upper troposphere water vapor, Geophys. Res. Lett., 21, 2701-2704, 1994.

Dessler, A. E. and Sherwood, S. C.: A matter of humidity, Science, 323, 1020-1021, doi:10.1126/science.1171264, 2009.

Dessler, A. E., Hintsa, E. J., Weinstock, E. M., and Anderson, J. G., Chan, K. R.: Mechanisms controlling water vapor in the lower stratosphere: "A tale of two stratospheres", J. Geophys. Res., 100, 23167-23172, 1995.

Dessler, A. E., Schoeberl, M. R., Wang, T., Davis, S. M., and Rosenlof, K. H.: Stratospheric water vapor feedback, P. Natl. Acad. Sci. USA, 110, 8087-18091, 2013.

Devasthale, A., Tjernström, M., Caian, M., Thomas, M. A., Kahn, B. H., and Fetzer, E. J.: Influence of the Arctic Oscillation on the vertical distribution of clouds as observed by the A-Train constellation of satellites, Atmos. Chem. Phys., 12, 10535-10544, doi:10.5194/acp-12-10535-2012, 2012.

Gettelman, A., Weinstock, E. M., Fetzer, E. J., Irion, F. W., Eldering, A., Richard, E. C., Rosenlof, K. H., Thompson, T. L., Pittman, J. V., Webster, C. R., and Herman, R. L.: Validation of Aqua satellite data in the upper troposphere and lower stratosphere with in situ aircraft instruments, Geophys. Res. Lett., 31, L22107, doi:10.1029/2004GL020730, 2004.

Groves, D. G. and Francis, J. A.: Variability of the Arctic atmospheric moisture budget from TOVS satellite data, J. Geophys. Res., 107, 4785, doi:10.1029/2002JD002285, 2002.

Hartmann, D. L., Klein Tank, A. M. G., Rusticucci, M., Alexander, L. V., Brönnimann, S., Charabi, Y., Dentener, F. J., Dlugokencky, E. J., Easterling, D. R., Kaplan, A., Soden, B. J., Thorne, P. W., Wild, M., and Zhai, P. M.: Observations: Atmosphere and Surface, in: Climate Change 2013: The Physical Science Basis. Contribution of Working Group I to the Fifth Assessment Report of the Intergovernmental Panel on Climate Change, edited by: Stocker, T. F., Qin, D., Plattner, G.-K., Tignor, M., Allen, S. K., Boschung, J., Nauels, A., Xia, Y., Bex, V., and Midgley, P. M., Cambridge University Press, Cambridge, United Kingdom and New York, NY, USA, 159-254, 2013.

Hegglin, M. I., Tegtmeier, S., Anderson, J., Froidevaux, L., Fuller, R., Funke, B., Jones, A., Lingenfelser, G., Lumpe, J., Pendlebury, D., Remsberg, E., Rozanov, A., Toohey, M., Urban, J., von Clarmann, T., Walker, K. A., Wang, R., and Weigel, K.: SPARC Data Initiative: Comparison of water vapor climatologies from international satellite limb sounders, J. Geophys. Res.-Atmos., 118, 11824-11846, doi:10.1002/jgrd.50752, 2013.

Herbin, H., Hurtmans, D., Clerbaux, C., Clarisse, L., and Coheur, P.-F.: $\mathrm{H}_{2}{ }^{16} \mathrm{O}$ and HDO measurements with IASI/MetOp, Atmos. Chem. Phys., 9, 9433-9447, doi:10.5194/acp-9-9433-2009, 2009.

Hess, P. G. and Lamarque, J.-F.: Ozone source attribution and its modulation by the Arctic oscillation during spring months, J. Geophys. Res., 112, D11303, doi:10.1029/2006JD007557, 2007. 
Highwood, E. J., Hoskins, B. J., and Berrisford, P.: Properties of the Arctic tropopause, Q. J. Roy. Meteorol. Soc., 126, 1515-1532, 2000.

Jakobson, E. and Vihma, T.: Atmospheric moisture budget in the Arctic based on the ERA-40 reanalysis, Int. J. Climatol., 30, 2175-2194, 2010.

Lacis, A. A., Schmidt, G. A., Rind, D., and Ruedy, R. A.: Atmospheric $\mathrm{CO}_{2}$ : Principal control knob governing Earth's temperature, Science, 330, 356-359, 2010.

Lambert, A., Read, W. G., Livesey, N. J., Santee, M. L., Manney, G. L., Froidevaux, L., Wu, D. L., Schwartz, M. J., Pumphrey, H. C., Jimenez, C., Nedoluha, G. E., Cofield, R. E., Cuddy, D. T., Daffer, W. H., Drouin, B. J., Fuller, R. A., Jarnot, R. F., Knosp, B. W., Pickett, H. M., Perun, V. S., Snyder, W. V., Stek, P. C., Thurstans, R. P., Wagner, P. A., Waters, J. W., Jucks, K. W., Toon, G. C., Stachnik, R. A., Bernath, P. F., Boone, C. D., Walker, K. A., Urban, J., Murtagh, D., Elkins, J. W., and Atlas, E.: Validation of the Aura Microwave Limb Sounder middle atmosphere water vapor and nitrous oxide measurements, J. Geophys. Res., 112, D24S36, doi:10.1029/2007JD008724, 2007.

Laroche, S., Gauthier, P., St-James, J., and Morneau, J.: Implementation of a $3 \mathrm{D}$ variational data assimilation system at the Canadian Meteorological Centre. Part II: The regional analysis, Atmos. Ocean, 37, 281-307, 1999.

Larson, J., Zhou, Y., and Higgins, R. W.: Characteristics of landfalling tropical cyclones in the United States and Mexico: Climatology and interannual variability, J. Climate, 18, 1247-1262, 2005.

Li, Y., Thompson, D. W. J., Huang, Y., and Zhang, M.: Observed linkages between the northern annular mode/North Atlantic Oscillation, cloud incidence, and cloud radiative forcing, Geophys. Res. Lett., 41, 1681-1688, doi:10.1002/2013GL059113, 2014.

Lumpe, J., Bevilacqua, R., Randall, C., Nedoluha, G., Hoppel, K., Russell, J., Harvey, V. L., Schiller, C., Sen, B., Taha, G., Toon, G., and Vömel, H.: Validation of Polar Ozone and Aerosol Measurement (POAM) III version 4 stratospheric water vapor, J. Geophys. Res., 111, D11301, doi:10.1029/2005JD006763, 2006.

McElroy, C. T., Nowlan, C. R., Drummond, J. R., Bernath, P. F., Barton, D. V., Dufour, D. G., Midwinter, C., Hall, R. B., Ogyu, A., Ullberg, A., Wardle, D. I., Kar, J., Zou, J., Nichitiu, F., Boone, C. D., Walker, K. A., and Rowlands, N.: The ACE-MAESTRO instrument on SCISAT: description, performance, and preliminary results, Appl. Opt., 46, 4341-4356, 2007.

Mo, K. C.: Relationships between low-frequency variability in the southern hemisphere and sea surface temperature anomalies, J. Climate, 13, 3599-3610, 2000.

Moss, A., Sica, R. J., McCullough, E., Strawbridge, K., Walker, K., and Drummond, J.: Calibration and validation of water vapour lidar measurements from Eureka, Nunavut, using radiosondes and the Atmospheric Chemistry Experiment Fourier Transform Spectrometer, Atmos. Meas. Tech., 6, 741-749, doi:10.5194/amt-6741-2013, 2013.

Murray, F. W.: On the computation of saturation vapor pressure, J. Appl. Meteorol., 6, 203-204, 1967.

Nedoluha, G. E., Bevilacqua, R. M., Hoppel, K. W., Lumpe, J. D., and Smit, H.: Polar Ozone and Aerosol Measurement III measurements of water vapor in the upper troposphere and lowermost stratosphere, J. Geophys. Res., 107, ACH7-1-ACH7-10, doi:10.1029/2001JD000793, 2002.
Oman, L., Waugh, D. W., Pawson, S., Stolarski, R. S., and Nielsen, J. E.: Understanding the changes of stratospheric water vapor in coupled chemistry-climate model simulations, J. Atmos. Sci., 65, 3278-3291, 2008.

Prospero, J. M., Charlson, R. J., Mohnen, V., Jaenicke, R., Delany, C., Moyer, J., Zoller, W., and Rahn, K.: The atmospheric aerosol system: An overview, Rev. Geophys., 21, 1607-1629, 1983.

Randel, W. J., Moyer, E., Park, M., Jensen, E., Bernath, P., Walker, K., and Boone, C.: Global variations of $\mathrm{HDO}$ and $\mathrm{HDO} / \mathrm{H}_{2} \mathrm{O}$ ratios in the upper troposphere and lower stratosphere derived from ACE-FTS satellite measurements, J. Geophys. Res., 117, D06303, doi:10.1029/2011JD016632, 2012.

Rydberg, B., Eriksson, P., Buehler, S. A., and Murtagh, D. P.: NonGaussian Bayesian retrieval of tropical upper tropospheric cloud ice and water vapour from Odin-SMR measurements, Atmos. Meas. Tech., 2, 621-637, doi:10.5194/amt-2-621-2009, 2009.

Shi, L. and Bates, J. J.: Three decades of intersatellitecalibrated High-Resolution Infrared Radiation Sounder upper tropospheric water vapor, J. Geophys. Res., 116, D04108, doi:10.1029/2010JD014847, 2011.

Sioris, C. E., Zou, J., McElroy, C. T., McLinden, C. A., and Vömel, H.: High vertical resolution water vapour profiles in the upper troposphere and lower stratosphere retrieved from MAESTRO solar occultation spectra, Adv. Space Res., 46, 642-650, 2010.

Sioris, C. E., Zou, J., McElroy, C. T., Boone, C. D., Sheese, P. E., and Bernath, P. F.: Water vapour variability in the high-latitude upper troposphere - Part 2: Impact of volcanic eruptions, Atmos. Chem. Phys., 16, 2207-2219, doi:10.5194/acp-16-22072016, 2016.

Soden, B. J. and Held, I. M.: An assessment of climate feedbacks in coupled ocean-atmosphere models, J. Climate, 19, 3354-3360, doi:10.1175/JCLI3799.1, 2006.

Soden, B. J., Jackson, D. L., Ramaswamy, V., Schwarzkopf, M. D., and Huang, X.: The radiative signature of upper tropospheric moistening, Science, 310, 841-844, 2005.

Steinbrecht, W., Köhler, U., Claude, H., Weber, M., Burrows, J. P., and van der A, R. J.: Very high ozone columns at northern mid-latitudes in 2010, Geophys. Res. Lett., 38, L06803, doi:10.1029/2010GL046634, 2011.

Su, H., Read, W. G., Jiang, J. H., Waters, J. W., Wu, D. L., and Fetzer, E. J.: Enhanced positive water vapor feedback associated with tropical deep convection: New evidence from Aura MLS, Geophys. Res. Lett., 33, L05709, doi:10.1029/2005GL025505, 2006.

Suen, J. Y., Fang, M. T., and Lubin, P. M.: Global distribution of water vapor and cloud cover sites for high-performance $\mathrm{THz}$ applications, IEEE Trans. Terahertz Sci. Technol., 4, 86-100, 2014.

Thompson, D. W. J. and Wallace, J. M.: Annular modes in the extratropical circulation. Part I: Month-to-month variability, J. Climate, 13, 1000-1016, 2000.

Toohey, M., Hegglin, M. I., Tegtmeier, S., Anderson, J., Añel, J. A., Bourassa, A., Brohede, S., Degenstein, D., Froidevaux, L., Fuller, R., Funke, B., Gille, J., Jones, A., Kasai, Y., Krüger, K., Kyrölä, E., Neu, J. L., Rozanov, A., Smith, L., Urban, J., von Clarmann, T., Walker, K. A., and Wang, R. H. J.: Characterizing sampling biases in the trace gas climatologies of the SPARC Data Initiative, J. Geophys. Res.-Atmos., 118, 1184711862, doi:10.1002/jgrd.50874, 2013. 
Treffeisen, R., Krejci, R., Ström, J., Engvall, A. C., Herber, A., and Thomason, L.: Humidity observations in the Arctic troposphere over Ny-Ålesund, Svalbard based on 15 years of radiosonde data, Atmos. Chem. Phys., 7, 2721-2732, doi:10.5194/acp-7-27212007, 2007.

Waymark, C., Walker, K. A., Boone, C. D., and Bernath, P. F.: ACEFTS version 3.0 data set: validation and data processing update, Ann. Geophys., 56, 6339, doi:10.4401/ag-6339, 2013.

Wiegele, A., Schneider, M., Hase, F., Barthlott, S., García, O. E., Sepúlveda, E., González, Y., Blumenstock, T., Raffalski, U., Gisi, M., and Kohlhepp, R.: The MUSICA MetOp/IASI $\mathrm{H}_{2} \mathrm{O}$ and $\delta \mathrm{D}$ products: characterisation and long-term comparison to NDACC/FTIR data, Atmos. Meas. Tech., 7, 2719-2732, doi:10.5194/amt-7-2719-2014, 2014.
Worden, J., Kulawik, S. S., Shephard, M. W., Clough, S. A., Worden, H., Bowman, K., and Goldman, A.: Predicted errors of tropospheric emission spectrometer nadir retrievals from spectral window selection, J. Geophys. Res., 109, D09308, doi:10.1029/2004JD004522, 2004. 